\title{
ON THE WAY TO THE AFTERLIFE. SOME OBSERVATIONS ON THE PRESENCE OF WEAPONRY IN EARLY MEDIEVAL CEMETERIES IN THE CONTEXT OF THEIR SOCIAL AND CULTURAL CIRCULATION
}

\begin{abstract}
The custom of burying the dead with weaponry depended on prevailing social norms and religious beliefs which determined the choice of a particular type of weapon to be placed in a pit grave. The primary activity here seems to be the act of withdrawal of selected elements of weaponry from further use for the purpose of including it in the posthumous equipment. This article addresses a few issues of this complex problem while taking account of early medieval finds, mainly from the territory of Poland. The presence of weapons in graves could result from many ways and trajectories of their circulation, which finally contributed to a certain configuration and choice of elements of weaponry both in terms of quality as well as quantity deposited in burials. Many of the pieces of weaponry had their own special "history" or "biography" before being placed in the grave. They could have belonged to an esteemed ancestor, commemorate some special event or participate in an exchange many times.
\end{abstract}

Keywords: early medieval weapons, territory of Poland, "biography" of weaponry, weapons in graves, posthumous equipment

Received: 13.06.2020 Revised: 02.07.2020 Accepted: 05.07.2020

Citation: Kurasiński T. 2020. On the Way to the Afterlife. Some Observations on the Presence of Weaponry in Early Medieval Cemeteries in the Context of Their Social and Cultural Circulation. "Fasciculi Archaeologiae Historicae" 33, 21-36, DOI 10.23858/FAH33.2020.002

The human environment at any time in history is marked by the presence of possessions which just like humans accumulate time, are in a state of flux and subject to continuous transformations. ${ }^{1}$ By demonstrating agency in all aspects of life they give testimony to continuous interactions between the human world and the material world and participation in establishing, maintaining and transforming these relations, which often takes on a ritual dimension. In the course of this process meanings, values and imagery are transferred to possessions which are in a state of constant flux. ${ }^{2}$ In this context the phenomenon of the circulation of material possessions needs to be considered significant as it is one of the signs of the social life of things. It is relevant for weaponry too, because it also participated in the

\footnotetext{
*Institute of Archaeology and Ethnology Polish Academy of Sciences, Łódź; (D https://orcid.org/0000-0002-8158-1104; tomasz.kurasinski@wp.pl

${ }^{1}$ Gosden and Marshall 1999, 169.

${ }^{2}$ Barański 2007, 257.
}

social and cultural circulation of goods in transition which was multi-dimensional and spread over time. In the Early Middle Ages depositing such goods in graves was one of the final stages of such circulation. The custom of burying the dead with weaponry depended on prevailing social norms and religious beliefs which determined the choice of which type of weapon to place in a pit grave. The primary activity here seems to be the act of withdrawal of selected elements of weaponry from further use for the purpose of including it in posthumous equipment. This article addresses a few issues of this complex problem while taking account of early medieval finds, mainly from the territory of Poland (Fig. 1).

$$
* * *
$$

On the basis of a variety of studies we gain knowledge of general mechanisms which determine in what way arms changed hands: be it systematically or incidentally while taking part in social and ritual processes of taking, accepting and discarding possessions. 


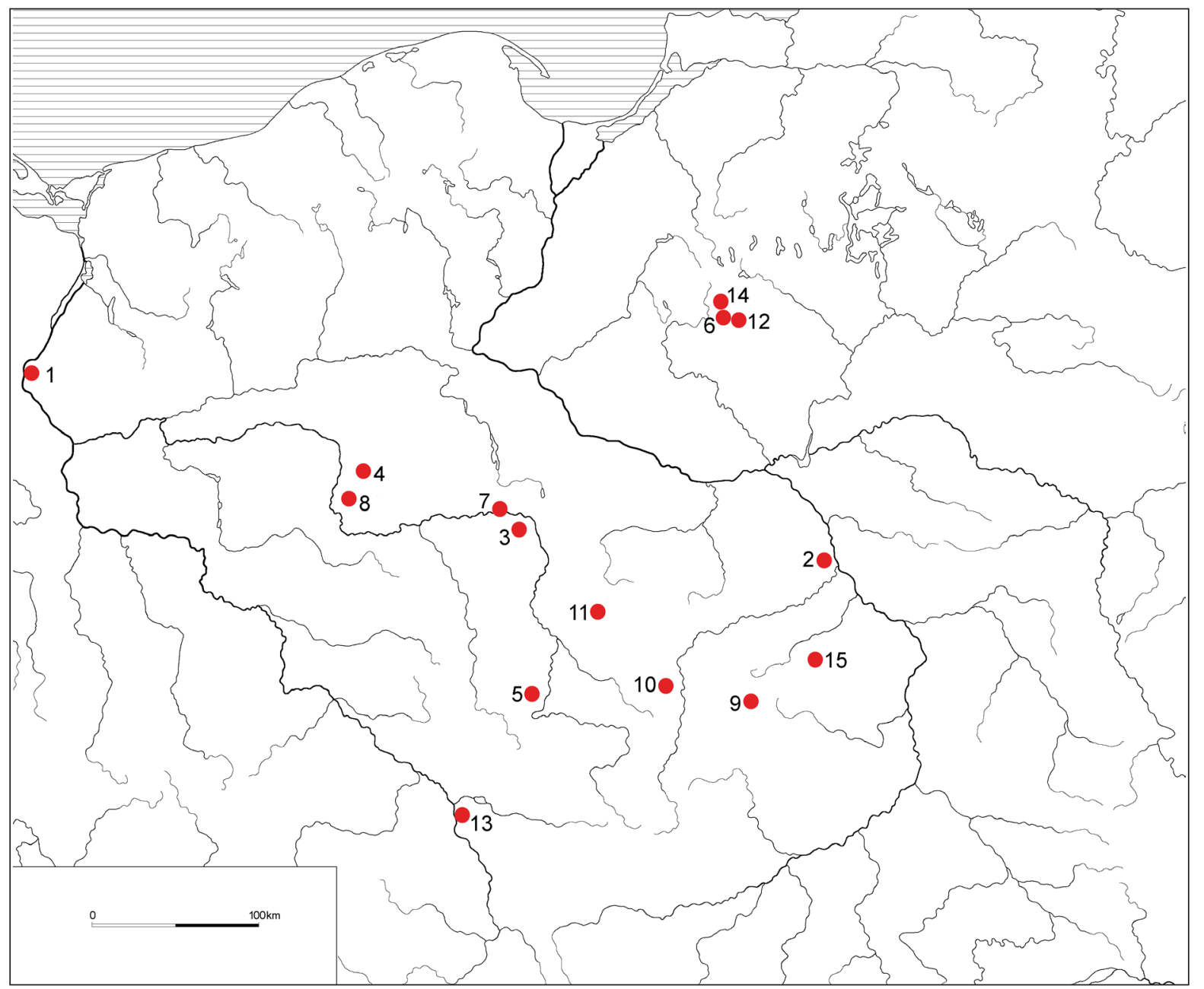

Fig. 1. Maps with localization of sites mentioned in the paper: 1 - Cedynia, Zachodniopomorskie Voivodeship; 2 - Czersk, Mazowieckie Voivodeship; 3 - Daniszew, Wielkopolskie Voivodeship; 4 - Dziekanowice, Wielkopolskie Voivodeship; 5 - Dębina, Łódzkie Voivodeship; 6 - Grzebsk, Mazowieckie Voivodeship; 7 - Konin, Wielkopolskie Voivodeship; 8 - Koninko, Wielkopolskie Voivodeship; 9 - Końskie, Świętokrzyskie Voivodeship; 10 - Lubień, Łódzkie Voivodeship; 11 - Lutomiersk, Łódzkie Voivodeship; 12 - Łączyno Stare, Mazowieckie Voivodeship; 13 - Opole-Nowa Wieś Królewska, Opolskie Voivodeship; 14 - Pokrzywnica Wielka, Mazowieckie Voivodeship; 15 - Radom, Mazowieckie Voivodeship. Elaborated T. Kurasiński.

H. Härke listed and then discussed four types of proceedings which contribute to the cultural circulation of weapons (Fig. 2):

- gift from lord to retainer (and between peers);

- gift from retainer to lord (including the heriot);

- heirloom;

- ritual depositions in graves and rivers. ${ }^{3}$

Moreover, the said researcher made a summary presentation of three basic ways which made the maintaining of the circulation of the category of goods discussed here possible and prevented the depletion of resources, namely: the production of new weapons, spoils of war and plundering graves. ${ }^{4}$

From the point of view of these considerations there is no need to discuss in detail all ways and

\footnotetext{
${ }^{3}$ Härke 2000, 377-390.

${ }^{4}$ Härke 2000, 390-393.
}

strategies of the circulation of weaponry in the Early Middle Ages in view of the limited possibility archaeology has for discerning gifts or spoils from finds uncovered in the course of archaeological excavations. ${ }^{5}$ However, the possibility that some weapons unearthed in this way were offered as such can by no means be excluded. ${ }^{6}$ Hence a few considerations should be made concerning the subject.

Almost the total body of knowledge concerning the circulation of various goods, including weaponry comes from written sources. We know that fellowship service was based on activities which aimed at establishing

\section{${ }^{5}$ Cf. Härke 2000, 380.}

${ }^{6}$ About handing down material goods (family heirlooms) as a kind of exchange between generations, which resulted in their extended circulation in the context of medieval funeral customs and found among grave goods see interesting observations by M. Kars 2013. 
and strengthening a relationship between a prince and/ or chieftain and the warriors under his command. For this purpose, material goods were necessary; they were mainly obtained as spoils of war, offered on various occasions, such as feasts ${ }^{7}$ and rallies. ${ }^{8}$ Nevertheless, a distinction would need to be made between offerings that aimed to establish specific human relationships and payment in gold under terms of an agreement concluded between the ruler and groups of mercenaries. ${ }^{9}$ It was only the generosity of a ruler that guaranteed the fealty, support and loyalty of those he ruled who were represented by his warriors and the wealthy. ${ }^{10}$ Offerings such as horses and weaponry were of particularly high value; of the latter most precious were swords, mail and helmets. ${ }^{11}$

From this perspective considering signs of repairs, changes or modifications as well as wear and tear which indicate a long period of use of some elements of weaponry, in particular swords, seems worthwhile. ${ }^{12}$ On the one hand, they would indicate placing great value, both material and emotional, on the possession of weaponry and the emotional bond, which showed in handing down weaponry as family heritage ${ }^{13}$ on the other hand, however, weaponry continuously changing hands, usually as spoils of war or offerings.

These mechanisms would sometimes make up a complicated "biography" of an object, examples of which can be found in written sources. For instance, a sword called 'Leg-Biter', mentioned in Laxdale Saga was initially in the possession of Geirmund: "It was a magnificent weapon; the pommel and guard were made of walrus ivory, without any silver, but the blade was very sharp and there was never any rust on it". ${ }^{14}$ However, at the end of the saga the sword changed not only its owner (Bolli Bollason), but also its appearance as its handle was covered in gold. ${ }^{15}$

${ }^{7}$ Gall, Kronika, I, 7, [24]; with commentary see Żmudzki 2005, 121; Żmudzki 2009, 335-336; cf. also Härke 2000, 391.

${ }^{8}$ Sawicki 1969, 143.

${ }^{9}$ P. Żmudzki gives a very good explanation in the context of early medieval Russian reality: "An offering was not considered in terms of payment, but as a means for establishing a much closer and lasting relationship than a mere contract of hire", Żmudzki 2004, 24. Simultaneously, the researcher indicates the possibility that some mercenaries were favoured by the chieftain; in this way they ceased to be strangers and became his own - Żmudzki 2004, 12-14, 24.

${ }^{10}$ Guriewicz 1976, 224, 227-228; Dalewski 2007, 41. According to the classic theory developed by M. Mauss, "The whole offering so given is permeated with the character of the offerer. The fact that it is in the hand of the receiver makes the contractor execute the contract, to redeem himself by redeeming the object", Mauss 2001, 282.

${ }^{11}$ Cf. Härke 2000, 379-383.

${ }^{12}$ Cf. Tokarski 1997, 57, 60.

${ }^{13}$ Tokarski 1997, 57.

${ }^{14}$ Laxdcela Saga, XXIX, 102.

${ }^{15}$ Laxdcela Saga, LXXVII, 228.
The fact that changes made both to the appearance and the construction are confirmed by weapon finds unearthed in the course of archaeological excavations. A part of a sword unearthed in one of the graves in Valsgärde (Sweden) was taken from some other piece. ${ }^{16}$ H. R. Ellis Davidson suggests that a little too short hilt found on some swords could have been the aftermath of damage to the tang, which resulted in the need to fix the pommel a bit lower. Such a change allowed for the further successful use of the sword. ${ }^{17}$ Swords found in northern and eastern Europe were made of elements which either dated to different periods or which were repaired. Many of them were unearthed in graves, such as a find from Novoselki near Smolensk (Russia). ${ }^{18}$

Finds recovered on the territory of modern-day Poland show signs which indicate attempts at keeping weapons in use by recycling them; these would include swords uncovered in grave 71 in Końskie ${ }^{19}$ and graves 10 and 16 in Pokrzywnica Wielka. ${ }^{20}$ In the first case the original pommel (type $\mathrm{Z}$ according to typology by J. Petersen), presumably due to wear or loss, was substituted by another one, which was formally more appropriate for a younger ('Romanesque') style of the hilt (Fig. 3:1). ${ }^{21}$ The pommel was also exchanged on one of the swords uncovered in Pokrzywnica Wielka, grave 16 although the authors of the study of the site do not exclude the possibility that the sword was originally made in the form which survived down to our times (Fig. 3:3). ${ }^{22}$ In the second find unearthed in the same graveyard the hilt which displayed features characteristic of type $\mathrm{X}$ was equipped with a chronologically older guard (type $\mathrm{S}$ ). This quite surprising discovery is confirmed by construction details visible in an X-ray, namely the opening of the guard is wider than the blade (Fig. 3:2). ${ }^{23}$

Before they were finally deposited, spurs would also circulate for a long time. An interesting find was uncovered in grave 3 in Grzebsk. Two spurs, which were typologically different, were unearthed at the bones of

\footnotetext{
${ }^{16}$ Ellis Davidson 1998, 13.

${ }^{17}$ Ellis Davidson 1998, 62.

${ }^{18}$ Androshchuk 2010, 267; Androshchuk 2014, 88-91, 197;
} Brunning 2019, 12, 61-88; Sayer et al. 2019, 549. It was the so called ceremonial swords that were subject to repair, first and foremost older elements were fixed on the hilt; that had ideological background and aimed to highlight the ageless nature of monarchy, see Janowski and Kurasiński 2009, 81.

${ }^{19}$ Gąssowski 1950, 130, Tab. X:14; Sarnowska 1955, 284, Fig. 12.

${ }^{20}$ Rauhut and Długopolska 1971, 304-305, 312, Tab. III:a-c, VI:a, Fig. 45.
${ }^{21}$ Strzyż 2006, 26
${ }^{22}$ Rauhut and Długopolska 1971, 334, 336, Tab. VI:a.
${ }^{23}$ Rauhut and Długopolska 1971, 334, 336, Tab. III:c. 


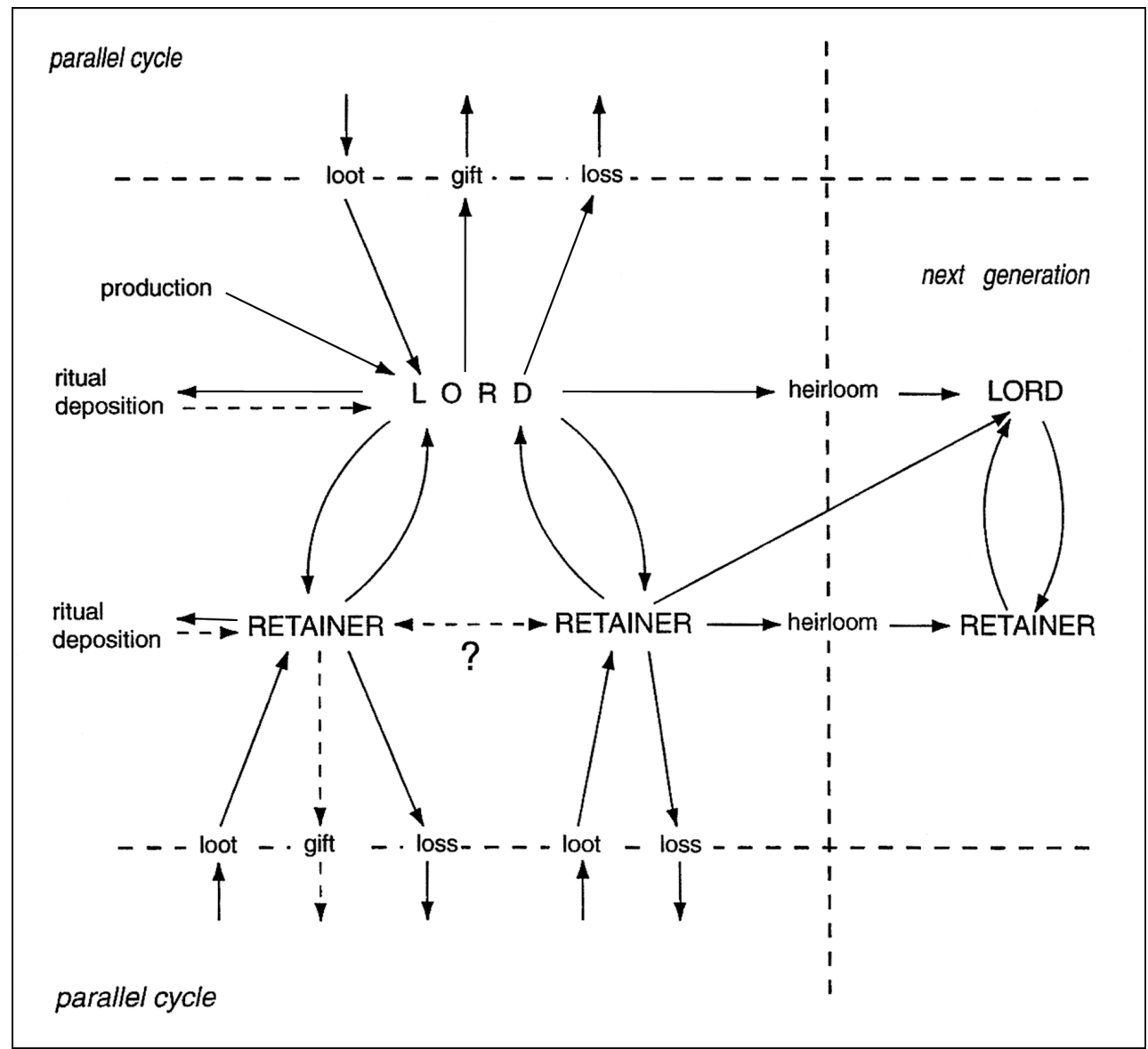

Fig. 2. Social and cultural circulation of early medieval weapons. After Härke 2000, Fig. 1. Elaborated T. Kurasiński.

the feet. ${ }^{24}$ Both belong to type II, according to the classification by Z. Hilczerówna, but one of them belongs to variant 1 (Fig. 4:2) which was used in the $10^{\text {th }}$ and the $1^{\text {st }}$ half of the $11^{\text {th }}$ century, while the other fits variant 3 (Fig. 4:1) whose timeline is between the middle of the $11^{\text {th }}$ and the beginning of the $13^{\text {th }}$ century. ${ }^{25}$ If we date the graveyard between the turn of the $11^{\text {th }}$ and the $12^{\text {th }}$ centuries and the middle of the $12^{\text {th }}$ century, it must be concluded that the former spur was a form which was already becoming obsolete while the latter was widely used at that time. According to R. Piotrowski, the deceased was offered weaponry which was not in use during his lifetime, but 'substitutes', although he would not exclude the possibility that despite formal differences the pieces could have been worn simultaneously as a pair. ${ }^{26}$ Regardless of which of the opinions is right, the fact is that the "life" of spurs type II: 1 started earlier and, presumably, lasted longer.

What must be puzzling in the context of studies on the circulation of goods in a society is the moment when an object ceased to be used by being placed in a pit grave. Hence the question about strategies and

\footnotetext{
${ }^{24}$ Zawadzka-Antosik 1973, 468-469, 484, Tab. II:a-b.

${ }^{25}$ Hilczerówna 1956, 45-46, 48-53.

${ }^{26}$ Piotrowski 2003, 174
}

criteria which were the overriding ones while making a decision about which weapon was to be deposited in a grave. Were there any at all?

In societies considered traditional ones "an eventful biography of a thing is for the most part one of events within the given sphere. Anything that does not fit the categories is clearly anomalous and it is taken out of normal circulation, to be either sacralized or isolated or cast out. What one glimpses through the biographies of both people and things in these societies is, above all, the social system and the collective understandings on which it rests". ${ }^{27}$ The fact of exploitation or damage to a weapon to such an extent that it was offered as grave goods might have been the criterion for such an inversion; in this way the requirements of rituals were met while simultaneously weaponry resources were not depleted.

The battle value of the repaired sword from Valsgärde mentioned earlier as well as other ones might have been lower in comparison to swords just made by sword-smiths. Other examples of damage or loss, which cannot be entirely attributed to being stored in the grave for a long time, might be pointed out as well. Damage can most clearly be seen on projectile points

${ }^{27}$ Kopytoff 1989, 89. 


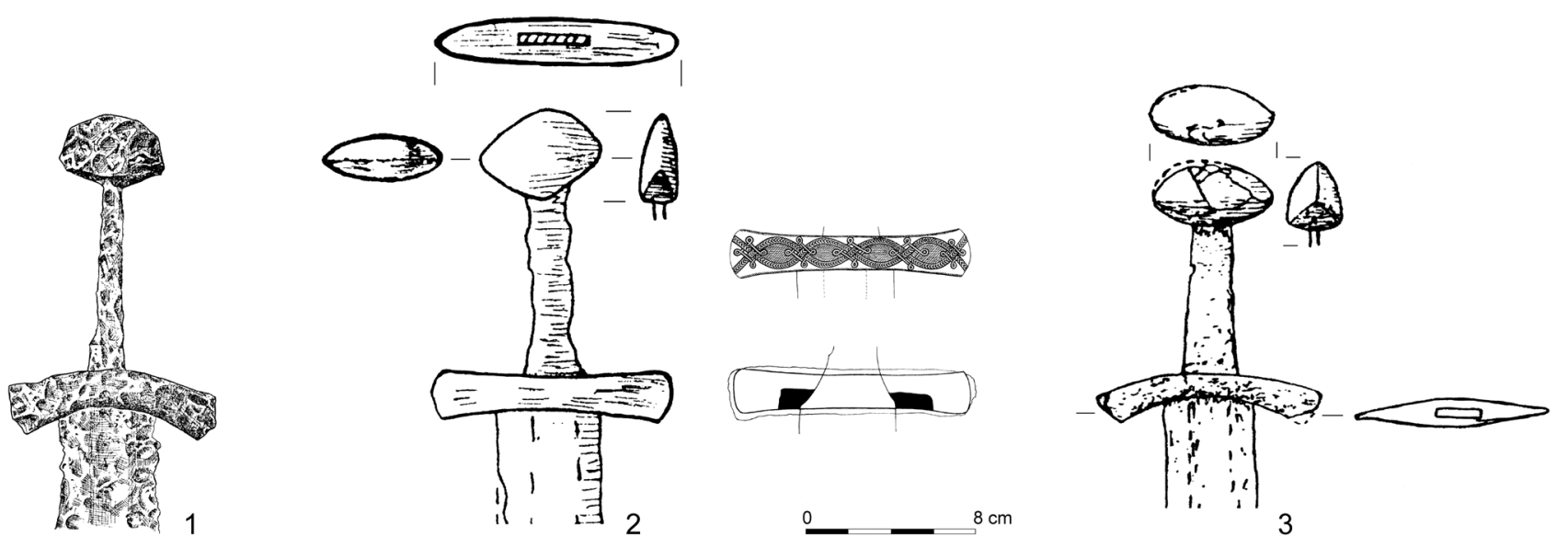

Fig. 3. Swords with a changed design from early medieval cemeteries: 1 - Końskie, grave 71. After Sarnowska 1955,

Fig. 12; 2 - Pokrzywnica Wielka, grave 10. After Rauhut and Długopolska 1971, Tab. III:a-c; 3 - Pokrzywnica Wielka, grave 16. After Rauhut and Długopolska 1971, Tab. VI:a. Elaborated T. Kurasiński.
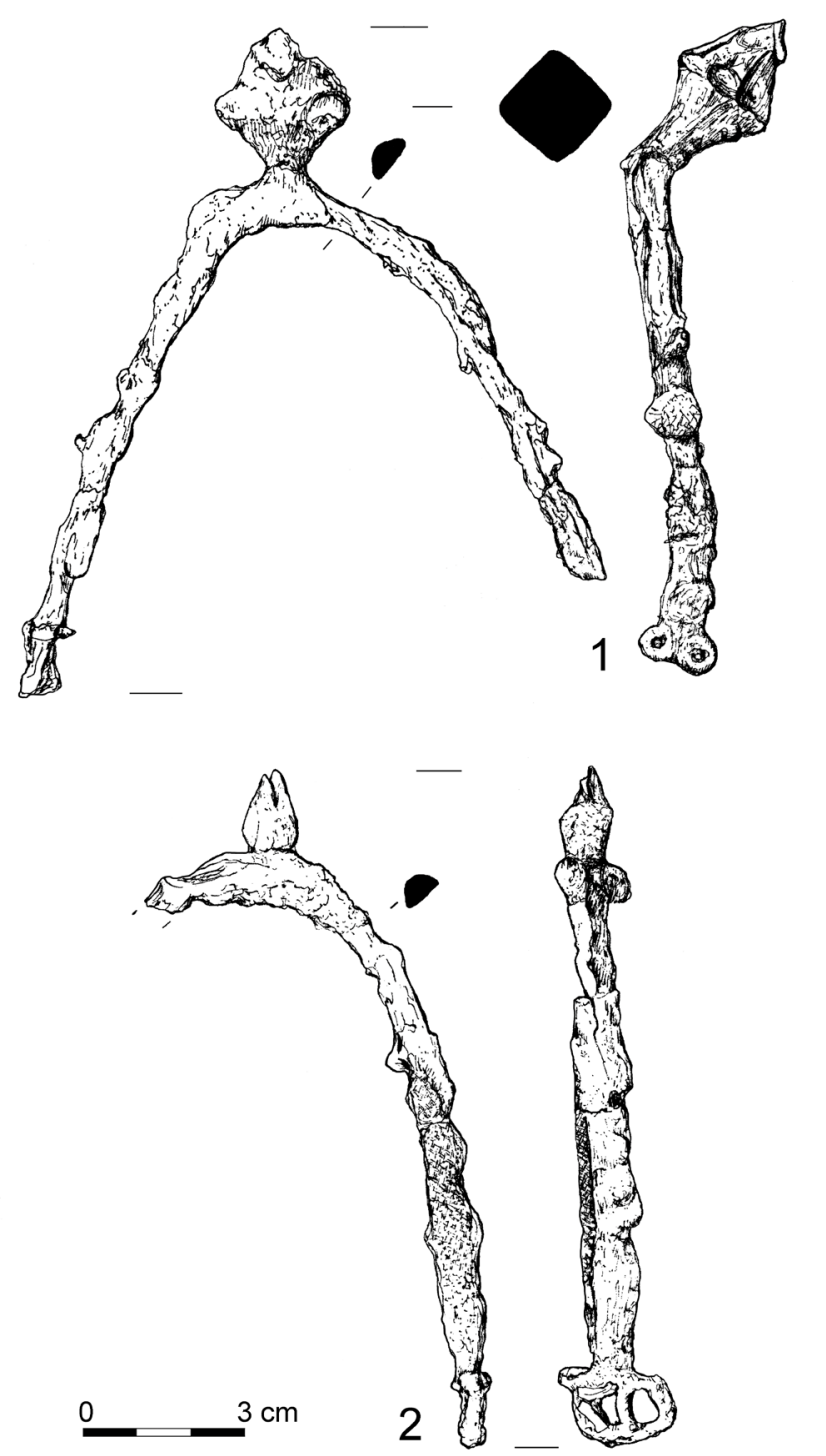

Fig. 4. Spurs from the early-medieval cemetery in Grzebsk, grave 3. After Zawadzka-Antosik 1973, Tab. II:a-b.

Elaborated T. Kurasiński. of pole weapon and on swords, however, there are also other categories of weapon, especially spurs and battle axes whose condition was poor; that might have been partly the result of long and intensive use.

Out of a rich collection of spear-, and javelin-heads unearthed in the graveyard in Lutomiersk many were damaged, often considerably, which shows mostly on the socket. In the case of some finds blade were broken, but the most fragmented one was an inlaid spearhead recovered in grave 5/49 (Fig. 5:1). ${ }^{28}$ Out of six spear-, or javelin heads uncovered in the graveyard in Pokrzywnica Wielka four (uncovered in graves 5, 15, 19 and 28) were broken, one of them twice (Fig. 5:2), and the socket of another one was considerably damaged (grave 16). ${ }^{29}$ Some other examples to be mentioned here would include a broken spear-head uncovered in grave 24/25 in Łączyno Stare (Fig. 5:3) ${ }^{30}$ as well as finds with missing tips of blades, e.g. in grave 3 in Daniszew. ${ }^{31}$ Some finds were fragmented, their considerable parts missing. In graveyard in Konin, grave 33 only a part of the socket with-base of a blade was uncovered under the skull (Fig. 5:4). ${ }^{32}$ Quite similar were finds uncovered in Cedynia, site 2, grave 622 (Fig. 5:5) ) $^{33}$ and Dębina, grave 11 (Fig. 5:6). ${ }^{34}$

The condition of some swords could also point to their excessive use. Of particular interest are finds uncovered

${ }^{28}$ Nadolski et al. 1959, 54, Tab. XXXVII:b.

${ }^{29}$ Rauhut and Długopolska 1971, 299, 310, 312, 316, 325, Tab. I:b, V:a, VI:c, VII:m, XI:c.

${ }^{30}$ Rauhut and Długopolska 1972, 345, Tab. VIII:c.

${ }^{31}$ Sawicki 2008, 182, Fig. 5:2.

${ }^{32}$ Kostrzewski 1946-1947, 196-197, 288, Fig. 4:3; Pieczyński 1967, 64.

${ }^{33}$ Malinowska-Łazarczyk 1982a， 32, Tab. XXVII:1; Malinowska-Łazarczyk 1982b, 150.

${ }^{34}$ Pokuta and Wojda 1979, 96, Tab. X:2. 

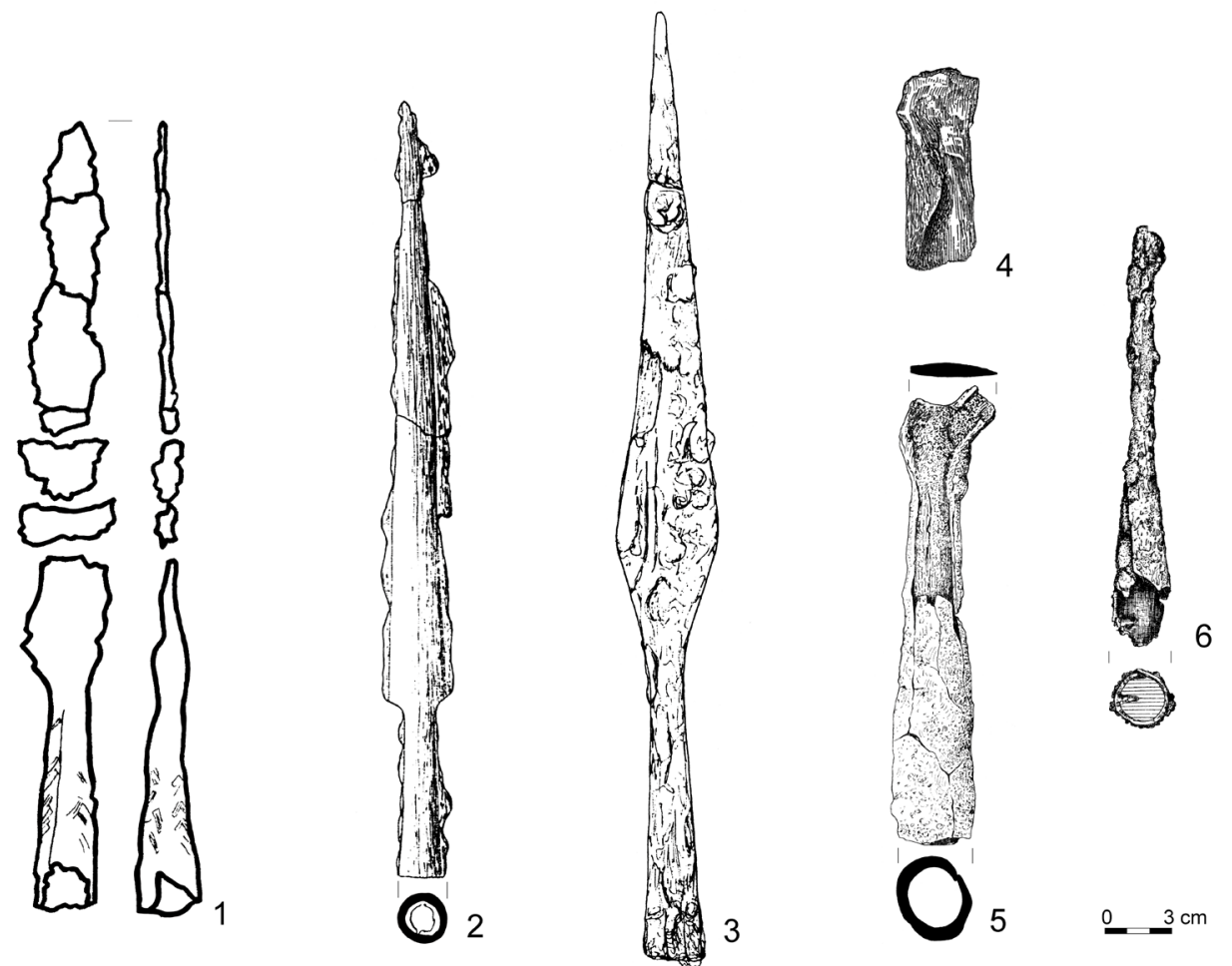

Fig. 5. Broken spearheads from early medieval cemeteries: 1 - Lutomiersk, grave 5/49. After Nadolski et al. 1959, Tab. XXXVII:b; 2 - Pokrzywnica Wielka, grave 15. After Rauhut and Długopolska 1971, Tab. V:a; 3 - Łączyno Stare, grave 24/25. After Rauhut and Długopolska 1972, Tab. VIII:c; 4 - Konin, grave 33. After Kostrzewski 1946-1947, Fig. 4:3; 5 - Cedynia, grave 622. After MalinowskaŁazarczyk 1982a, Tab. XXVII:1; 6 - Dębina, grave 11. After Pokuta and Wojda 1979, Tab. X:2. Elaborated T. Kurasiński.

in graveyard in Pokrzywnica Wielka. Except for one, all swords unearthed on the dig (from graves 10, 16, 19 and 31) were either incomplete or broken (Fig. 6:14). ${ }^{35}$ The blade of a sword unearthed in grave 609 in Czersk is broken into four parts (Fig. 6:5). ${ }^{36} \mathrm{~A}$ find uncovered in graveyard in Koninko, grave 11 also showed numerous damage (Fig. 6:6). ${ }^{37}$ Its blade in the upper part is broken twice, ${ }^{38}$ while the lower part is clearly bent and the tip is missing. Moreover, the cross-guard whose one end did not survive due to corrosion was positioned slant and the pommel was moved towards the tang. These are just a few examples. While searching for reasons of the above mentioned phenomenon the fact of handing down weaponry to heirs also needs to be mentioned here. Undoubtedly, weaponry, and especially swords were handed down as heritage of the house from generation to generation, also as a form of legacy handed down to people who were neither relative nor in-law, sometimes also to ecclesiastical

\footnotetext{
${ }^{35}$ Rauhut and Długopolska 1971, 304-305, 312, 316, 326 328, Tab. III:a, VI:a, VII:i, XI:1.

${ }^{36}$ Rauhutowa 1972, 151, Fig. 4; Bronicka-Rauhut 1998, 42, Tab. 6:10, Fig. 83:1.

37 Stępnik 2009, 276-277, Fig. 4; Stępnik et al. 2014.

${ }^{38}$ According to T. Stępnik damage was probably suffered during modern building works - Stępnik 2009, 277; Stępnik et al. 2014,148 .
}

institutions. ${ }^{39}$ This is indicated by written sources as well as grave findings.

Source analysis of the will (c. 1015 AD) of Æthelstan Ætheling, the eldest son of King Æthelred II, indicates that weapon which was most precious both in material (decorated swords and mail) and symbolic terms (sword which used to "belong to King Offa" was distributed among members of his family and household. The remains of his war gear, less numerous, were offered to other people from the entourage of the sovereign, among whom there was a priest; moreover, one of the swords was offered to the church in which Æthelstan was buried. ${ }^{41}$

A reference to The Saga of the Volsungs, in which we can read about handing down damaged weapon, also seems valuable. King Sigmund, during fights in a battle hit Odin's spear and broke the blade in two.

${ }^{39}$ Cf. Härke 2000, 383-386.

${ }^{40}$ According to $\mathrm{H}$. Härke the claim does not necessarily need to be true; nevertheless the researcher does not agree that the sword has a long timeline and gives archaeological examples of archaic weaponry offered as grave goods, Härke 2000, 393-394. See also footnote 18

${ }^{41}$ Härke 2000, 384-385, Tab. 2; Androshchuk 2010, 266-267; Tollerton 2011, passim; Androshchuk 2014, 194-196; Brunning 2019, 136-138; here are further examples of similar bequests. Text of Æthelstan's will in: Anglo-Saxon Wills, 57-63. 

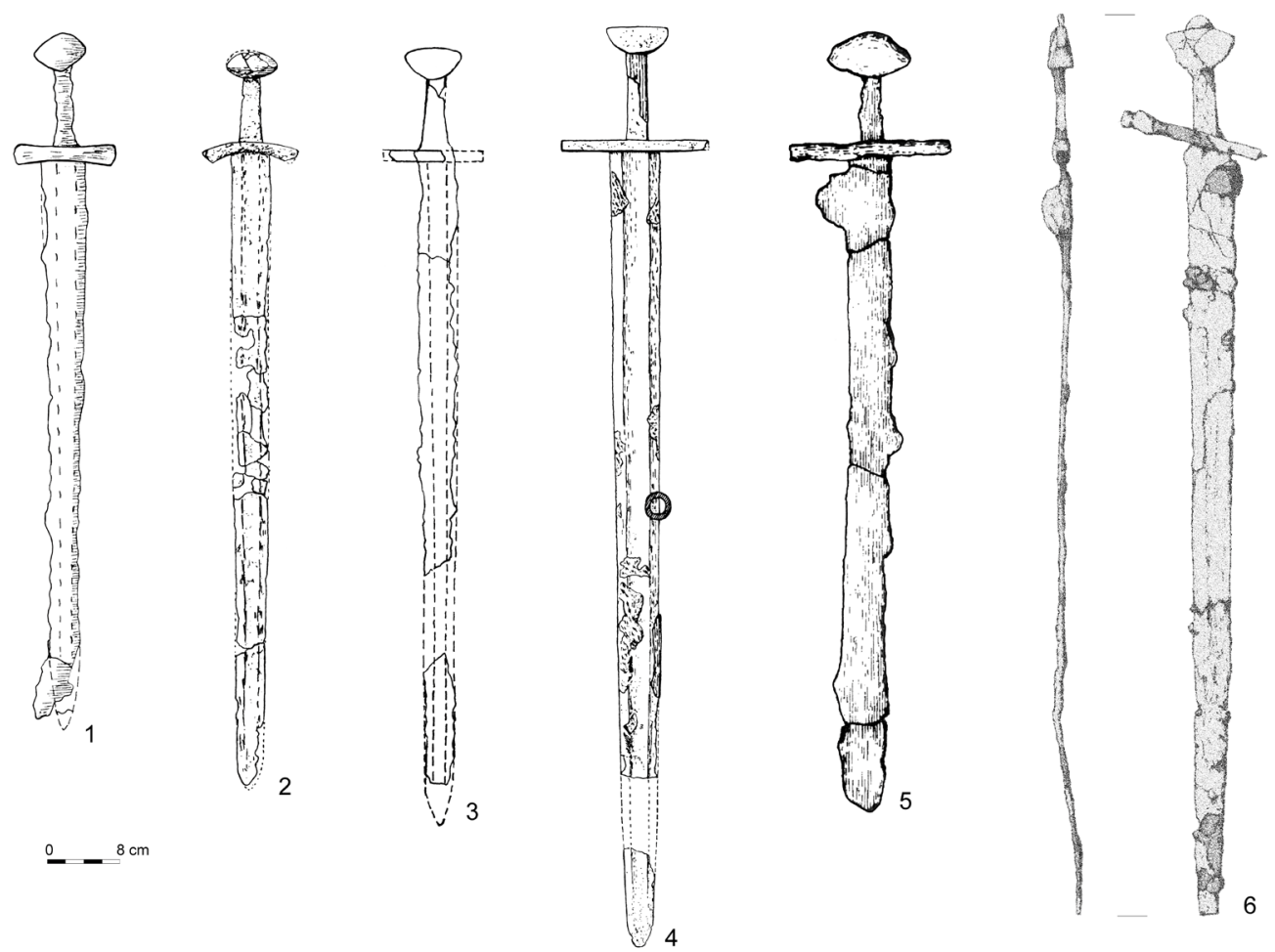

Fig. 6. Incomplete and broken swords from early medieval cemeteries: 1 - Pokrzywnica Wielka, grave 10. After Rauhut and Długopolska 1971, Tab. III:a; 2 - Pokrzywnica Wielka, grave 16. After Rauhut and Długopolska 1971, Tab. VI:a; 3 - Pokrzywnica Wielka, grave 19. After Rauhut and Długopolska 1971, Tab. VII:i; 4 - Pokrzywnica Wielka, grave 19. After Rauhut and Długopolska 1971, Tab. XI:1; 5 - Czersk, grave 609.

After Bronicka-Rauhut 1998, Fig. 83:1; 6 - Koninko, grave 11. After Stępnik 2009, Fig. 4:b. Elaborated T. Kurasiński.

The remains of the weapon were to be guarded by Hjördis and passed on their unborn son, Sigurd. The new sword forged from the remains was called Gram and had exceptional qualities in a battle..$^{42}$ An equally interesting note about handing down a spear and a horn by a dying Bohemian king, Bretislav II to his younger son is included in the chronicle of Cosmas of Prague. ${ }^{43}$

Elements of combat equipment handed down that way, mainly swords, were precious pieces, although their true value was not determined by precious metals or artwork. ${ }^{44}$ Such a weapon might even have been rusty or made of lesser materials, provided it were part of glorious history. ${ }^{45}$ This is confirmed by other findings as well. In the Middle Ages the sword, as a special sign of memory, legitimised possessions and other

\footnotetext{
${ }^{42}$ Saga o Völsungach, 11-12, 15 [29-30, 37-38].

${ }^{43}$ Kosmas, Kronika, III, 13, [331]. Regardless of the fact that the act together with other objects which were relevant to it is interpreted as a symbolic taking over of power to dispose land which was private property of the duke by the successor (Charvát 2000), it also gives evidence of inheriting weapon and keeping it in circulation. It needs also be noted that the possession of inherited weapon was an important prerequisite for respect and status. Its loss or giving away could mean losing a social status - Androshchuk 2010, 267; Androshchuk 2014, 197.

${ }^{44}$ Tollerton 2011, 189, 194-195.

${ }^{45}$ Androshchuk 2010, 268; Androshchuk 2014, 200.
}

prerogatives. It was the 'old and rusty' pieces of said weaponry which served as evidence in disputes; they were material evidence of continuous legal title to property or privilege. ${ }^{46}$

A hypothetical testimony of inheriting weapon, albeit in the negative sense, are grave goods recovered by archaeologists. Damaged and broken blades - intentional as sometimes suggested ${ }^{47}$ - are interpreted by many researchers in legal terms as a sign of lack of heirs who could inherit the sword, which as a result could mean the expiry of patrilineality. ${ }^{48}$ Such a conclusion could be made with regard to the spearhead unearthed in Pokrzywnica Wielka (grave 15), which might have been broken before it was deposited in the grave (Fig. 5:2).$^{49}$ It needs to be admitted, however, that

\footnotetext{
${ }^{46}$ As the example of $13^{\text {th }}$ century English reality shows, see Klusek 2010.

${ }^{47}$ Rauhut and Długopolska 1971, 316, 336; Bronicka-Rauhut $1998,42$.

${ }^{48}$ E.g. Dziewanowski 1989, 18; Żygulski Jr. 1975, 42; Wrzesiński 1997-1998, 14; Piotrowski 2003, 187; Biborski et al. 2004 , 190. According to some researchers, a sword should not fall into the hands of someone else after the death of its owner, hence it should be destroyed, Korzukhina 1950, 64-65; Grinsell 1961, 477.

${ }^{49}$ According to L. Rauhut and L. Długopolska (1971, 343) the evidence that the dead buried in a grave in Pokrzywnica "was the only surviving heir of the house or the family at that
} 
we do not have any direct 'archaeological' evidence to support the concept discussed here; it seems to be more of research intuition than a fact confirmed for the period which is subject to these considerations.

Cases of breaking, bending or fragmenting weaponry are also associated with ritual requirements arising out of, to give an example, fear of the dead who could regain power symbolised by the weapon and disturb the living. ${ }^{50}$ Another hypothesis worth considering holds that depriving the weapon of its military value by wilful damage was to demonstrate braveness and tenacity while fighting the enemy of the buried warrior. ${ }^{51}$ Making a weapon useless could also result from utilitarian reasons; it prevented its further use and simultaneously prevented the grave from being plundered. ${ }^{52}$ In this case it presumably sufficed to depreciate the most valuable grave goods, such as swords. ${ }^{53}$ Without delving more deeply into the matter, suffice it to say that beyond any doubt we deal with a conglomeration of rites, practices and beliefs which are relevant to weaponry and the necessity to make it useless by its ritual "killing". ${ }^{44}$

Another aspect worth considering concerns the qualitative and quantitative composition of weaponry deposited in graves. While studying finds uncovered in the territory of Poland, it needs to be stressed that the collection was not representative of full combat gear. There was a clear deficiency of riding horses, and especially arm protections. ${ }^{55}$ There are also few burials in which weapons were represented by more than one weapon category. ${ }^{56}$ This is also the thesis noted earlier in Polish literature on the subject, while the presence of limited types of weaponry among grave goods or only single finds was interpreted in economic and social terms. Presuming that burial with weaponry was a sign of belonging of the buried to a privileged social group, it sufficed to deposit only a part of the armour or only one, selected from a whole collection of weaponry. This way goods, sometimes of considerable value, could be kept for future generations. ${ }^{57}$ The

time" was the very fact of depositing numerous and valuable grave goods. According to other interpretations weapon in children's graves would more likely prove the need to compensate lack of taking over social roles which were assigned to them or future ones, Kowalczyk 2003, 123, footnote 29.

${ }^{50}$ Åström 1987, 216-217; Traschel 2005, 78.

${ }^{51}$ Biborski 1981, 61; Kurasiński 2011, 223.

52 Ellis Davidson 1998, 11; Trachsel 2005, 78.

${ }^{53}$ Karvonen 1998, 7.

${ }^{54}$ More on this phenomenon see Zemitis 2006; Kurasiński 2011, 219-224; Măndescu 2012; Biro 2016; Aannestad 2018; Husár 2018, 58-59; Jahn 2018.

${ }^{55}$ See Sikora 2014, 303-304.

${ }^{56}$ Dataset in Kurasiński 2012.

${ }^{57}$ See Nadolski 1954, 93; Nadolski 1963, 113; Nowakowski 1983, 198 possibility of inheriting weaponry mentioned earlier, which meant their scarce representation in pit graves was also indicated by W. Sarnowska, who gave a positive answer to the question she posed, "Perhaps the warrior was offered complete weaponry only when he had neither children nor relatives who would inherit from him and who could avenge his death?". ${ }^{58}$ In this case we would deal with practical application of the pars pro toto principle. ${ }^{59}$

It seems that the lack of complete collections of weapons in a grave could have been due to other reasons as well. It needs to be taken into account that resources of weaponry kept running out due to longer or shorter periods of increased demand for weapons and shortages of arms. Such a situation could prevail in conditions of increased war operations, lack of continuous production or supply of weapons. Nevertheless, the presumption that the number of graves with grave goods including weapon should be increased in the period of intense war activities cannot be excluded, primarily due to a shorter average lifespan and intense participation of warriors in military activities. However, during his studies of Anglo-Saxon history H. Härke noted that it was a period of relative peace $\left(1^{\text {st }}\right.$ half of the $6^{\text {th }}$ century) that marked the peak of the custom of burying the dead with elements of weaponry. ${ }^{60}$ Hence he concluded that the striving to express heroic mythology supported by myths, which could not be done in the time of war, was strengthened by rituals in the interludes punctuating military operations. ${ }^{61}$ Nevertheless, much simpler conclusion would be to state that the phenomena discussed here resulted directly from increased demand for weapon in times of turmoil.

Unfortunately, with regard to the territory of Poland we do not have the opportunity to examine the relationship between the burials with grave goods in the form of weapon and war activities that Piast rulers engaged in. On the one hand this is due to insufficient precision while dating graves subject to study. Although there are certain periodic fluctuations, however, any attempt at establishing any interdependence of graves and political events confirmed by sources, even disregarding the diverse development of individual provinces during the period of fragmentation - would go too far beyond the margin of probability. The general tendency is to a decrease in the number of graves with weapons in successive centuries, which would need to be associated rather with the mental and spiritual changes which were taking place due the spread of Christian faith. On

\footnotetext{
${ }^{58}$ Sarnowska 1956, 51.

${ }^{59} \mathrm{Cf}$. Kontny 2008, 107.

${ }^{60}$ Härke 1990, 28, 30 [Diagram]; Härke 1997, 124, Fig. 2.

${ }^{61}$ Härke 1997, 124.
} 

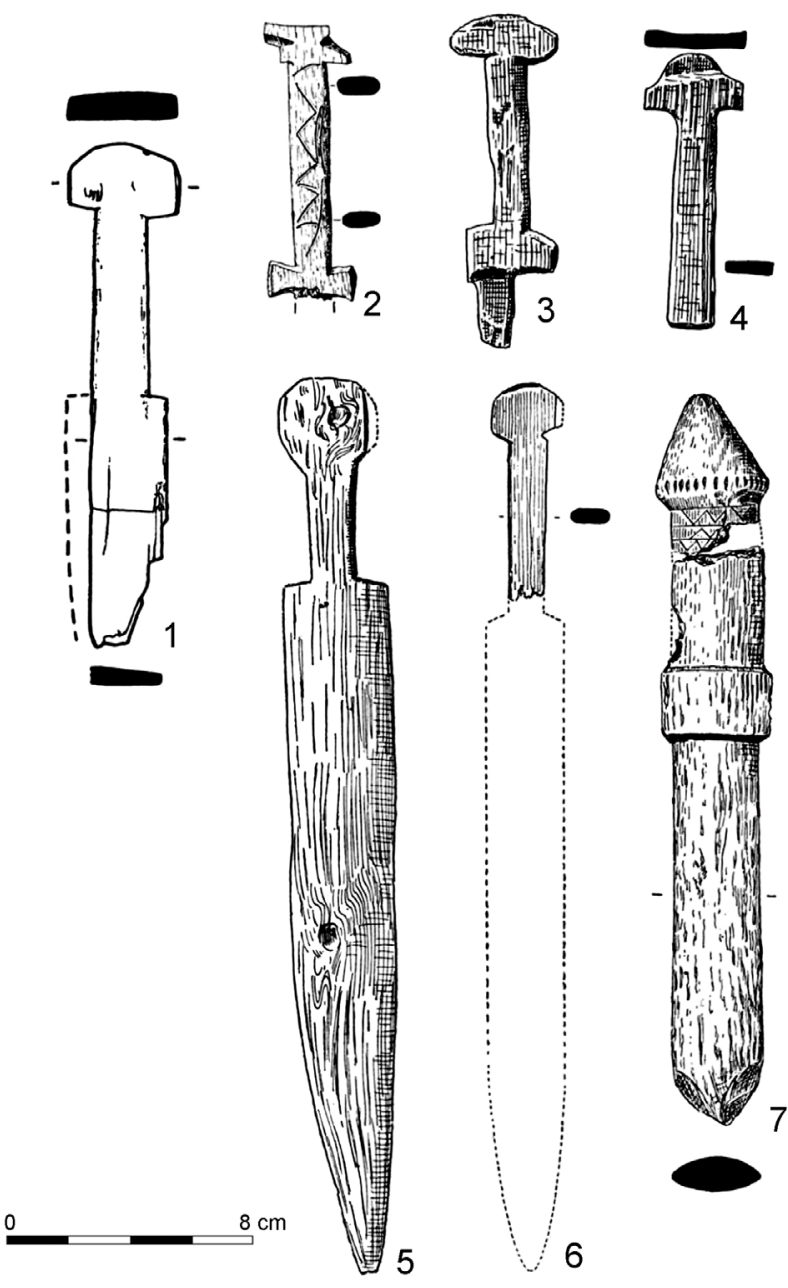

Fig. 7. Selection of wooden swords from Polish lands:

1- Opole; 2 - Gdańsk; 3-4 - Nakło; 5 - Szczecin; 6-7 - Wolin.

After Kotowicz 2008, Fig. 1. Elaborated T. Kurasiński.

the other hand, however, it would be difficult to indicate any clear period of armistice at the early stages of the development of Poland's statehood. The custom of furnishing graves with elements of weapons together with other burial customs (e.g. inhumation, organisation of graveyards) appeared in the course of the $10^{\text {th }}$ century in conditions of abrupt transformations relevant to the establishment of early Piast statehood and continued until the beginning of the $13^{\text {th }}$ century. During that period many armed conflicts took place, both external as well as domestic. Of particular significance was the rule of Bolesław the Brave, whose expansionist politics favoured many wars and skirmishes, especially with his Western neighbours in 1002-1005, 1007-1013 and 1015-1018. Events which took place in the 1020s marked an important threshold; it was a time of social unrest due to the so-called pagan reaction ${ }^{62}$ and the raid

${ }^{62}$ The 'archaeological record' of the said turmoil is discussed by S. Moździoch 2005 . of Bretislav, Duke of Bohemia to bring back the relics of St. Adalbert, and ultimately with the aim to conquer Poland. ${ }^{63}$ The raid resulted in the fall of the first Piast Monarchy. Coming back from exile, Casimir I the Restorer managed to reunite Polish lands and open a new chapter in the history of the country (the second Piast Monarchy), which started to be ruled on entirely new principles. Many wars, especially with Bohemia, were fought by Boleslaw II the Bold and his successors. The rule of Bolesław III Wrymouth was marked with conflict with his brother, Zbigniew and the conquest of Pomerania. The Statute of Succession (1138) marked yet another threshold and resulted in the fragmentation of the Polish state and family conflicts within the dynasty over seniority. The above incidents must have resulted in transformations concerning the organisation of armed forces and social structures ${ }^{64}$ and finally also with regard to burial rites, however, tracing regularities which would be confirmed by archaeological sources would be difficult to prove today.

It seems that not only the factor of accessibility of weapon was the factor that determined its presence in the grave. A lot depended on the value ascribed to individual elements of weaponry, and those were not to be strictly subordinated to represent the reality of a battle, but might have been relevant to the need to represent identity of the deceased and the memory of him, mostly in an idealised way, without the need to deposit a real and complete military equipment. ${ }^{65}$ Most probably the act of depositing weapon in the grave, irrespective of its kind - albeit the sword and spurs must have been of special importance ${ }^{66}$ - was ennobling and ensured social consolidation, both for the buried but also (or rather first of all) for all the mourners, who most probably were closest relatives (collective identities). ${ }^{67}$

Times of war or other historic turmoil or the choice of weapon made with a view to creating a social profile of the dead did not necessarily result in the total

\footnotetext{
${ }^{63}$ See Matla-Kozłowska and Baran-Kozłowski 2009.

${ }^{64}$ See Bogacki 2007; Jurek 2007; with further extensive
} literature.

${ }^{65}$ Sikora 2014, 305, 307; see also Vandkilde 2006, 485, 486. Following cultural anthropologists focusing on the study of material culture it seems worth mentioning that "material goods make up a code of things, which sets the meaning simultaneously ascribing value: to an individual and a group, circumstances, functions and situations", Barański 2007, 342

${ }^{66}$ See recently Goßler 2013; Brunning 2019; Sayer et al. 2019.

${ }^{67}$ Proposed by M. Kars "The model of intergenerational transmission shows that material culture (from graves) can be studied as a component of various relations between groups and individuals, and not just as the reflection of static identities such as an unchanging personal status, legal position, ethnic identity or religious affiliation", Kars 2013, 102. 
disappearance of weapons from graves or their limitation to selected items. There might have only been a temporary reduction of their collection, which was complemented by depositing 'substitute' items made of materials less durable than metals.

Some elements of armoury, especially shields, bows and arrows, and saddles were made mostly of organic materials and for that reason they were subject to complete degradation. ${ }^{68}$ Also, other items of weaponry might have been made in whole of such materials. For example, instead of metal stirrups sometimes wooden ones were in use, possibly loops were made of string or leather. ${ }^{69}$ Spears/javelin, ${ }^{70}$ cudgels/clubs ${ }^{71}$ and swords were also made of materials which were not durable, in other words, those were their practice versions (Fig. 7). ${ }^{72}$

The issue of how such weapon functioned has been discussed in a broad chronological and cultural context by T. Capelle. This author was of the opinion that elements of weaponry made from non-durable materials were used not only in times when knowledge and skill of obtaining and working metals was unknown, but also later, including medieval times. Moreover, the possession of wooden weapon did not depend on social status of its owner. ${ }^{73}$ In later period the issue was also studied by other researchers who showed that weapon made of organic materials was more often used in the past than it could be inferred on the basis of source materials which have survived down to our times. ${ }^{74}$

Hence using such items could have resulted in creating a "biased" picture of military equipment deposited as grave goods due to their disintegration and destruction and therefore create the risk of making an erroneous assumption regarding the original contents of the grave. ${ }^{75}$

This conclusion is equally relevant to the damage of a grave, which occurred while the graveyard was in use, or during later use of the land (e.g. by farmers) where it was located. Grave plundering also needs to be taken into account, ${ }^{76}$ although in the case of grave fields in the territory of Poland no clear traces of such plundering of graves have been noted.

Alleged assigning weaponry made of lesser materials for grave goods makes us ask a question whether

${ }^{68}$ Nadolski 1954, 77.

${ }^{69}$ Nadolski 1954, 89.

${ }^{70}$ Kontny 1996.

${ }^{71}$ Kontny 2015.

${ }^{72}$ Kotowicz 2008; see also Roskoschinski 2011; sceptically Weski 1994; Cosack 2012.

${ }^{73}$ Capelle 1982.

${ }^{74}$ Roskoschinski 2010; Schatte 2013; Martens 2019.

${ }^{75}$ Cf. Bochnak 2006, 156-157.

${ }^{76}$ See e.g. Kümmel 2009; Klevnäs 2013. among weapons unearthed in graveyards there were any finds of no combat value. A possible indication which could help identify such finds would be given by results of specialist physiochemical, X-ray, metallurgical or technological examination. It needs to be stated, however, that at our present stage of research the results of specialist examination known to us, mostly of swords and rarely of other types of weaponry, such as spearheads or axe heads do not allow us to indicate beyond any doubt objects which were a substitute or imitation of 'real' objects. Almost all objects which were subject to analysis were made to the highest possible quality standards which were to assure battle efficiency. The high symbolic value of a sword as well as spurs as a symbol arose out of their practical value in a battle, which defined the social background of riders. Such a function could only be performed by "original" weapons, hence only in exceptional cases were copies which could not be used in battle deposited as grave goods. ${ }^{77}$

The fact that a weapon was used in a battle shows in marks of damage: chips, cuts or repairs visible on many pieces of weaponry deposited in graves; nevertheless, as mentioned earlier, a considerable part of the damage might have been due to other reasons.

The issue touched on here definitely calls for further detailed studies on the basis of extended series of analyses, also using materials from outside the territory of Poland. ${ }^{78}$ Both a axe and spear unearthed in graveyard in Radom (graves 29 and 41) the iron elements of which show no advanced technology of production aimed to improve their combat qualities, seems worth considering. No blade overlays, traces of carbonization or hardening were found. ${ }^{79}$

Similarly, other weaponry unearthed in pit graves could hardly be used in a battle, albeit for reasons other than those above mentioned. A battle axe head unearthed in a graveyard in Pień was decorated with silver inlaid patterns; its combat value is questionable as any hard strike, presumably, could result in loosening of the inlaid sheet of silver, which in turn would also result in depreciation of its aesthetic qualities.$^{80}$ Finds of inconsiderable size should also be regarded in rather symbolic than utilitarian terms, such as miniature

\footnotetext{
${ }^{77}$ See Meier 2002, 147-148.

${ }^{78}$ Polish literature on the subject sometimes mentions the possibility of making weaponry for sepulchral purposes Sierosławski and Weker 2013, 48; cf. Husár 2009, 206, 209; Fleming 2012, 25.

${ }^{79}$ Klimek et al. 2013; see also Kurasiński and Skóra 2012a, 81-83.

${ }^{80}$ Drozd and Janowski 2007, 122. According to other researchers battle axes with decorated heads were made specifically for combat purposes, Nadolski 1954, 38; Głosek 1987, 210.
} 
battle axes unearthed in Dziekanowice (grave 65/95), Opole-Nowa Wieś Królewska (grave 56) and Lubień (grave 85), which were uncovered in children's graves. ${ }^{81}$

The collection of weaponry unearthed in graves might have resulted from existing burial customs. As noted earlier, there was a deficiency of protective weaponry and elements of horse tack, which is interpreted as ritual selection, which gave priority to certain categories of weaponry over others. Presumably, local burial customs did not provide for burial of the dead with equipment that would define a horse rider; and simultaneously his social status, apart from, naturally, spurs which were a frequent find. ${ }^{82}$ According to J. Sikora, "absence of protective equipment might have been relevant to some sort of a taboo, which prevented the mourners from depositing such elements of military equipment". ${ }^{83}$

Regional differences with regard to territorial distribution of grave with weapons should also be considered. In southern Poland weapons can hardly ever be found in the collection of grave goods; unlike other parts of Poland, i.e. Grater Poland or Mazovia, where rich collections of weaponry, both in terms of quality as well as quantity can be found. This, however, can perhaps be put down to different burial practices. ${ }^{84}$

One hypothetical reason for such a difference could be the custom of placing weapons not inside the pit grave, but outside, on the element marking the place of burial, such as a stone or a cross. Such a situation is described by L. Kovács, who gives an account of placing the shafts of spears on a burial spot to mark it and to highlight the rank of the dead by Magyars which date back to the time of conquering the territory which was to become their homeland (at the turn of the $9^{\text {th }}$ and $10^{\text {th }}$ centuries), as well as other tribes, which is confirmed by written sources and ethnographical data. The researcher is of the opinion that this is the reason why there were so few spearheads in old Magyar graves which date back to that time. ${ }^{85}$ Although in graves of interest to us it was pole weapons that dominated in collections of grave goods, such a possibility, however, should be taken into account. Such a function could also have been exercised by other types of weapon, such as arrows or battle axes, whose share in stray finds unearthed in graveyards dating back to the early Piast period is high. It needs to be noted that ethnographic literature mentions depositing battle axes on graves e.g. by Lusatians. ${ }^{86}$

It seems that some ritual and magic phenomena which can be observed in graveyards (unusual position of weaponry next to the skeleton or their wilful damage) which echo beliefs and imagery difficult to comprehend could also influence the way in which weaponry was used in burial customs and, as a result, its presence in graves.

$$
* * *
$$

This study is but a handful of reflections and observations concerning the phenomenon of furnishing graves with weapons as one of the links in the circulation of these material goods in the social life of things. The discussion undertaken here indicates that the presence of weaponry in graves could result from many ways and trajectories of their circulation, which finally contributed to a certain configuration and choice of elements of weaponry both in terms of quality as well as quantity, as well as other elements in the collection of grave goods deposited in burials. Most likely, many of the pieces of weaponry had their own special 'history' or 'biography' before being placed in the grave. They could have belonged to an esteemed ancestor, commemorate some special event or participate in an exchange many times. As a result of activities which aimed at selecting an object, elements that met the requirements of the battlefield or ceremonial, as well as the presence of less valuable materials, or physical states beyond repair or their being unfit for processing or simply old-fashioned, could be deposited in graves. It needs to be borne in mind, however, that the circulation of goods was by no means a constant phenomenon, and therefore regulations governing said processes, for example due to religious transformations (the spread of Christianity) or social ones could have resulted in changes in the way they were deposited. ${ }^{87}$ The issue discussed here is worth further extended studies, which on the one hand would require an individual approach to each case where a weapon is uncovered, and on the other hand would need a theoretical basis concerning the circulation of material goods in the past.

\footnotetext{
${ }^{81}$ See Kurasiński 2009, 218-223; Kurasiński and Skóra 2012b, 47 .

${ }^{82}$ See Nadolski 1954, 126, footnote 14; Nadolski 1963, 113-114.

${ }^{83}$ Sikora 2014, 304.

${ }^{84}$ See Sikora 2014, 306.

${ }^{85}$ Kovács 1970, 108; Kovács 1977, 68-72; Kovács 1982; with further literature.
} 


\section{Sources}

Gall, Kronika - Gall Anonim, Kronika polska, ed. M. Plezia, transl. R. Grodecki. Skarby Biblioteki Narodowej. Wrocław 2003.

Kosmas, Kronika - Kosmasa Kronika Czechów, ed. and transl. M. Wojciechowska. Warszawa 1968.

Laxdcela Saga - Laxdcela Saga, ed. and transl. M. Magnusson, H. Pálsson. London 1975.

Saga o Völsungach - Saga o Völsungach, ed. and transl. R. Leśniakiewicz. Sandomierz 2009.

Anglo-Saxon Wills - Anglo-Saxon Wills, transl. and ed. D. Whitelock. Cambridge 2011.

\section{Bibliography}

Aannestad H. L. 2018. Charisma, Violence and Weapons. The Broken Swords of the Vikings. In: M. Vedeler, I. M. Rørstad, E. S. Kristoffersen, Z. T. Glørstad (eds.), Charismatic Objects. From Roman Times to the Middle Ages. Oslo, 147-166.

Androshchuk F. 2010. The Gift to Men and the Gift to the Gods: Weapon Sacrifices and the Circulation of Swords in Viking Age Society. In: C. Theune, F. Biermann, R. Struwe, G. H. Jeute (eds.), Zwischen Fjorden und Steppe. Festschrift für Johan Callmer zum 65. Geburstag. Rahden/Westf., 263-275.

Androshchuk F. 2014. Viking Swords. Swords and Social Aspects of Weaponry in Viking Age Societies. Stockholm.

Åström P. 1987. Intentional Destruction of Grave Goods. "Aegaeum” 1, 213-218.

Barański J. 2007. Świat rzeczy. Zarys antropologiczny. Kraków.

Biborski M. 1981. Grób wojownika kultury przeworskiej z okresu wpływów rzymskich z Gostomi, woj. Radom a niektóre aspekty zwiazane z rytualnymi śladami niszczenia broni. "Materiały Archeologiczne" 21, 49-63.

Biborski M., Stępiński J., Żabiński G. 2004. A Renaissance Sword from Racibórz. "Gladius" 24, 187-208.

Biro A. 2016. Notes on the Tenth-Century Magyar Bow. Mutilated, Ruptured and Broken Lateral Tip Plates in the Tenth-Eleventh-Century Archaeological Material of the Carpathian Basin. In: Á. Bollók, T. Vida (eds.), Zwischen Byzanz und der Steppe. Archäologische und historische Studien Festschrift für Csanád Bálint zum 70. Geburtstag / Between Byzantium and the Steppe Archaeological and Historical Studies in Honour of Csanád Bálint on the Occasion of His 70 Birthday. Budapest, 605-621.

Bochnak T. 2006. Panoplie de guerrier et tombe de guerrier. Problème de la pertinence des trouvailles sépulcrales (d'après des exemples de culture de Przeworsk à la période préromaine précoce). In: S. A. Luca, V. Sîrbu (eds.), The Society of the Living - the Community of the Dead (from Neolithic to the Christian Era). Proceedings of the $7^{\text {th }}$ International Colloquium of Funerary Archaeology. Acta Terrae Septemcastrensis 5(1) (special number). Sibiu, 152-163.

Bogacki M. 2007. Przemiany w wojskowości polskiej od polowy X wieku do 1138 roku. Ksztatt i organizacja armii. Toruń.

Bronicka-Rauhut J. 1998. Cmentarzysko wczesnośredniowieczne w Czersku. Warszawa.

Brunning S. 2019. The Sword in Early Medieval Northern Europe. Experience, Identity, Representation. Woodbridge.

Capelle T. 1982. Erkenntnismöglichkeiten ur- und frühgeschichtlicher Bewaffnungsformen. Zum Problem von Waffen aus organischem Material. "Bonner Jahrbücher" 182, 265-288.

Charvát P. 2000. „Dejte mému synáčkovi loveckou trubku mou a kopi”: co vlastně odkázal umírajíci Břetislav II. svému dědici? "Acta Historica et Museologica Universitatis Silesianae Opaviensis" 5, 167-169.

Cossack E. 2012. Waren die Germanen auch mit Holzschwertern in der ,,Varusschlacht" bewaffnet? "Nachrichten aus Niedersachsen Urgeschichte" 81, 287-303.

Dalewski Z. 2007. Władca i możni w Kronice Galla Anonima. In: M. Nodl, M. Wihoda (eds.), Šlechta, moc a reprezentace ve středověku,. Colloquia Mediaevalia Pragensia 9. Praha, 31-44.

Drozd A., Janowski A. 2007. Wczesnośredniowieczny topór inkrustowany z miejscowości Pień na ziemi chetmińskiej. In: M. Bogacki, M. Franz, Z. Pilarczyk (eds.), Wojskowość ludów Morza Bałtyckiego. Materiaty z II Międzynarodowej Sesji Naukowej Dziejów Ludów Morza Bałtyckiego, Wolin 4-6 sierpnia 2006. Toruń, 106-127.

Dziewanowski W. 1989. Zarys dziejów uzbrojenia w Polsce. Warszawa.

Ellis Davidson H. R. 1998. The Sword in Anglo-Saxon England. Its Archaeology and Literature. Woodbridge.

Fleming R. 2012. Recycling in Britain after the Fall of Rome's Metal Economy. "Past and Present" 217(1), 3-45. 
Gąssowski J. 1950. Cmentarzysko w Końskich na tle zagadnienia poludniowej granicy Mazowsza we wczesnym średniowieczu. "Materiały Wczesnośredniowieczne" 2, 71-175.

Głosek M. 1987. Stan i perspektywy badań nad średniowiecznymi toporami w Polsce. "Prace i Materiały Muzeum Archeologicznego i Etnograficznego w Lodzi. Seria Archeologiczna” 34, 207-211.

Gosden C, Marshall Y. 1999. The Cultural Biography of Objects. "World Archaeology" 31(2), 169-178.

Goßler N. 2013. Zur Deutung von Gräbern mit Sporenbeigabe im westslawischen Raum. In: F. Biermann, Th. Kersting, A. Klammt (eds.), Soziale Gruppen und Gesellschaftsstrukturen im westslawischen Raum. Beiträge der Sektion zur slawischen Frühgeschichte der 20. Jahrestagung des Mittel- und Ostdeutschen Verbandes für Altertumsforschung in Brandenburg (Havel), 16. bis 18. April 2012. Beiträge zur Ur- und Frühgeschichte Mitteleuropas 70. Langenweissbach, 77-94.

Grinsell L. V. 1961. The Breaking of Objects as a Funerary Rite. "Folklore" 72(3), 475-491.

Guriewicz A. 1976. Kategorie kultury średniowiecznej. Warszawa.

Härke H. 1990. ,, Warrior Graves”? The Background of the Anglo-Saxon Weapon Burial Rite. "Past and Present" 126(1), 22-43.

Härke H. 1997. Material Culture as Myth: Weapons in Anglo-Saxon Graves. In: C. Kjeld Jensen, K. Høilund Nielsen (eds.), Burial \& Society. The Chronological and Social Analysis of Archaeological Burial Data. Aarhus, 119-127.

Härke H. 2000. The Circulation of Weapons in Anglo-Saxon Society. In: F. Theuws, J. L. Nelson (eds.), Rituals of Power. From the Late Antiquity to the Early Middle Ages. Leiden, Boston, Köln, 377-399.

Hilczerówna Z. 1956. Ostrogi polskie z X-XIII wieku. Poznań.

Husár M. 2009. Hroty kopijï/oštepov z obdobia včasného stredoveku v Karpatskej kotline z hl'adiska metalografie. In: E. Bútorová, E. Kováčová (eds.), Veda v praxi-prax vo vede. Nitra, 205-214, 223-229.

Husár M. 2018. Pokus o výklad niektorých otáznych spôsobov deponovania kopiji a oštepov do hrobov včasnostredovekej Karpatskej kotliny. "Konštantínove listy" 11(1), 51-66.

Jahn Ch. 2018. ,, Sulaužytas kalavijas “: Linkūnu ginklai/,, The Broken Sword”: Weapons in Linkuhnen. In: A. Bliujienè (ed.), Klaipèdos (Memel) kraštas: nuo ištaku iki XVII amžiaus. Paroda ir katalogas, skiriami Lietuvos valstybès šimtmečiui ir Europos kultūros paveldo metams 2018 / The Klaipèda (Memel) Region: from Origins to the $17^{\text {th }}$ Century. The Exhibition and the Catalogue are Dedicated to the Centennial of the Restored State of Lithuania and European Year of Cultural Heritage 2018. Klaipeda, 178-182.

Janowski A., Kurasiński T. 2009. Miecz i pochwa-razem i osobno. Wstęp do problematyki. In: P. Kucypera, P. Pudło, G. Żabiński (eds.), Arma et Medium Aevum. Studia nad uzbrojeniem średniowiecznym. Toruń, 74-115.

Jurek T. 2007. Geneza szlachty polskiej. In: M. Nodl, M. Wihoda (eds.), Šlechta, moc a reprezentace ve středověku. Colloquia Mediaevalia Pragensia 9. Praha, 63-140.

Kars M. 2013. The Early-medieval Burial Evidence and Concepts of Possession: Questioning Individual Identities. In: B. Ludowici (ed.), Individual and Individuality? Approaches Towards an Archaeology of Personhood in the First Millennium AD. Neue Studien zur Sachsenforschung 4. Hannover, 95-106.

Karvonen J. 1998. Deliberately Damaged Objects in Iron Age Cremation Cemeteries. With Reference to the Objects from the Cremation Cemeteries of Ylipää in Lieto and Päivääniemi in Lempäälä. "Fennoscandia archaeological" 15, 3-13.

Klevnäs A. M. 2013. Whodunnit? Grave Robbery in Anglo-Saxon England and the Merovingian Kingdoms. British Archaeological Raports. International Series 2582. Oxford.

Klimek L., Kurasiński T., Skóra K. 2013. Metallographic Analyses of Military Items from the Early Medieval Inhumation Cemetery in Radom, site 4. "Fasciculi Archaeologiae Historicae" 26, 25-39.

Klusek B. 2010. Gladius antiquus et eruginatus. Miecz medium poświadczającym prawo w Anglii dojrzałego średniowiecza. In: A. Zglińska, P. Pranke (eds.), Pamiętać czy zapomnieć. Miejsca pamięci we współczesnym dyskursie naukowym. Warszawa, 51-64.

Kontny B. 1996. Oszczepy wykonane z materiałów organicznych w okresach przedrzymskim i rzymskim. Próba określenia w materiale archeologicznym. In: W. Nowakowski (ed.), Concordia. Studia ofiarowane Jerzemu Okuliczowi-Kozarynowi w sześćdziesiąta piata rocznicę urodzin. Warszawa, 147-157.

Kontny B. 2008. The War as Seen by an Archaeologist. Reconstruction of Barbarian Weapons and Fighting Techniques in the Roman Period Based on the Analysis of Graves Containing Weapons. The Case of the Przeworsk Culture. In: L. Kocsis (ed.), The Enemies of Rome, Proceedings of the 15th International Roman Military Equipment Conference, Budapest 2005. Journal of Roman Military Equipment Studies 16. Budapest, 107-145.

Kontny B. 2015. Was Tacitus Right? On the Existence of Hitting Weapons of Organic Materials Amongst the Balt Tribus. In: S. Wefers, M. Karwowski, J. Fries-Knoblach, P. Trebsche, P. C. Ramsl (eds.), Waffen - Gewalt 
- Krieg. Beiträge zur Internationalen Tagung der AG Eisenzeit und des Instytut Archeologii Uniwersytetu Rzeszowskiego - Rzeszów 19.-22. September 2012. Beiträge zur Ur- und Frühgeschichte Mitteleuropas 79. Langenweissbach, 271-283.

Kopytoff I. 1986. The Cultural Biography of Things: Commoditization as Process. In: A. Appadurai (ed.), The Social Life of Things. Commodities in Cultural Perspective. Cambridge, 64-91.

Korzukhina G. F. 1950. Iz istorii drevnerusskogo oruzhiya XI veka. "Sovetskaya arkheologia" 13, 63-94.

Kostrzewski B. 1946-1947. Cmentarzysko z okresu rzymskiego w Koninie (woj. poznańskie). "Przegląd Archeologiczny" 7(2), 192-294.

Kotlyarevski A. 1868. O pogrebal'nykh obychajach jazycheskikh Slavyan. Moskva.

Kotowicz P. N. 2008. Zabawka czy oręż ćwiczebny? Przyczynek do badań nad problematyka drewnianych naśladownictw średniowiecznych mieczy. In: W. Świętosławski (ed.), Nie tylko broń. Niemilitarne wyposażenie wojowników w starożytności i średniowieczu. Acta Archaeologica Lodziensia 54. Łódź, 89-98.

Kovács L. 1970. A honfoglaló Magyarok lándzsái és lándzsástemetkezésük. "Alba Regia” 11, 81-108.

Kovács L. 1977. Über die ungarischen Lanzen aus dem 10.-11. Jahrhundert. "Mitteilungen des Archäologischen Instituts der Ungarischen Akademie der Wissenschaften" 7, 61-73, 222-224.

Kovács L. 1982. A honfoglaló magyar lándzsák sirrjelölés és néprajzi megfelelöi. In: M. Hoppál, L. Novák (eds.), Elömunkálatok a magyarság néprajzához 10. Budapest, 58-86.

Kowalczyk E. 2003. Dzieje granicy mazowiecko-krzyżackiej (między Drwęca a Pisa). Warszawa.

Kümmel Ch. 2009. Ur- und frühgeschichtlicher Grabraub. Archäologische Interpretation und kulturanthropologische Erklärung. Münster, New York, München, Berlin.

Kurasiński T. 2009. Militaria jako element wyposażenia wczesnośredniowiecznych pochówków dziecięcych-próba interpretacji na przyktadzie znalezisk z ziem polskich. "Archeologia Polski" 54(2), 209-248.

Kurasiński T. 2011. Lamanie, zginanie, wbijanie. O kilku nietypowych zabiegach dotyczacych uzbrojenia na wczesnośredniowiecznych cmentarzyskach szkieletowych z ziem polskich. In: O. Ławrynowicz, J. Maik, P. A. Nowakowski (eds.), Non sensistis gladios. Studia ofiarowane Marianowi Gtoskowi w 70. rocznice urodzin. Łódź, 219-236.

Kurasiński T. 2012. Wczesnośredniowieczne groby z elementami uzbrojenia na terenie ziem polskich (X-XIII w.). Unpublished doctoral thesis. Manuscript in the Archive of Institute of Archaeology and Ethnology Polish Academy of Sciences, Łódź.

Kurasiński T., Skóra K. 2012a. Militaria z wczesnośredniowiecznego cmentarzyska szkieletowego w Radomiu, stan. 4. "Acta Militaria Mediaevalia" 8, 69-89.

Kurasiński T., Skóra K. 2012b. Wczesnośredniowieczne cmentarzysko szkieletowe w Lubieniu, pow. piotrkowski. Łódź.

Malinowska-Łazarczyk H. 1982a. Cmentarzysko średniowieczne w Cedyni 1. Szczecin.

Malinowska-Łazarczyk H. 1982b. Cmentarzysko średniowieczne w Cedyni 2. Szczecin.

Măndescu D. 2012. Killing the Weapons. An Insight on Graves with Destroyed Weapons in Late Iron Age Transylvania. In: S. Berecki (ed.), Iron Age Rites and Rituals in the Carpathian Basin. Proceedings of the International Colloquium from Târgu Mureș 7-9 October 2011. Târgu Mureș, 343-356.

Martens J. 2019. From Ultima Thule to the Hellespont - Some Remarks on the Bone Points of the Iron Age. In: O. Munteanu, V. Iarmulschi (eds.), Interdisciplinary Study of the Pre-Roman and Roman Iron Age in Central and South Eastern European Barbaricum. Dedicated to Professor Michael Meyer. "Plural" 7(2), 43-52.

Matla-Kozłowska M., Baran-Kozłowski W. 2009. Gall i Kosmas o wydarzeniach końca lat 30. XI wieku w Polsce: wyprawa Brzetysława w wersji ,polskiej” $i$,, czeskiej”. In: Z. Górczka, J. Jaskulski (eds.), Wielkopolska - Polska - Czechy. Studia z dziejów średniowiecza ofiarowane Profesorowi Bronisławowi Nowackiemu. Poznań, 33-46.

Mauss M. 2001. Szkic o darze. Forma i podstawa wymiany w spoleczeństwach archaicznych. In: M. Mauss, Socjologia i antropologia. Warszawa, 163-306.

Meier Th. 2002. Die Archäologie des mittelalterlichen Königsgrabes im christlichen Europa. Stuttgart.

Moździoch S. 2005. Gens perfida et nondum bene christiana - konfrontacja chrześcijaństwa i wierzeń tradycyjnych $w$ państwie pierwszych Piastów w świetle najnowszych odkryć archeologii. In: A. Pieniądz-Skrzypczak, J. Pysiak (eds.), Sacrum. Obraz i funkcja w spoteczeństwie średniowiecznym. Warszawa, 67-82.

Nadolski A. 1954. Studia nad uzbrojeniem polskim w X, XI i XII wieku. Acta Archaeologica Universitatis Lodziensis 3. Łódź.

Nadolski A. 1963. Zabytki uzbrojenia jako źródło do dziejów polskiego średniowiecza. "Studia Źródłoznawcze" 8, 112-115. 
Nadolski A., Abramowicz A., Poklewski T. 1959. Cmentarzysko z XI wieku w Lutomiersku pod Łodzia. Acta Archaeologica Universitatis Lodziensis 7, Łódź.

Nowakowski A. 1983. Historia uzbrojenia a dzieje polskiego średniowiecza. "Wiadomości Historyczne" 148(26), 187-208.

Pieczyński Z. 1967. Cmentarzysko z okresu wędrówek ludów i z wczesnego średniowiecza z Konina. "Fontes Archaeologici Posnanienses" 18, 54-67.

Piotrowski R. 2003. Uwagi na temat chronologii i interpretacji wczesnośredniowiecznych cmentarzysk mazowieckich. "Archeologia Polski" 48(1-2), 165-200.

Pokuta Z., Wojda L. 1979. Wczesnośredniowieczne cmentarzysko we wsi Dębina, woj. sieradzkie. "Prace i Materiały Muzeum Archeologicznego i Etnograficznego w Łodzi. Seria Archeologiczna" 26, 89-142.

Rauhut L., Długopolska L. 1971. Wczesnośredniowieczne cmentarzysko szkieletowe w obudowie kamiennej w Pokrzywnicy Wielkiej, pow. Nidzica. "Wiadomości Archeologiczne" 36(3), 292-353.

Rauhut L., Długopolska L. 1972. Wczesnośredniowieczne cmentarzysko szkieletowe w obudowie kamiennej w Łaczynie Starym, pow. Przasnysz. "Wiadomości Archeologiczne" 37(3), 320-393.

Rauhutowa J. 1972. Wczesnośredniowieczny grobowiec z XII w. z Czerska pod Warszawa. "Archeologia Polski" 17(1), 143-160.

Roskoschinski Ph. 2010. Keule, Speer und Schwert aus Holz - Hölzerne Waffen oder Hölzer in Waffengestalt? "Museumsjournal für Natur und Mensch" 6, 209-231.

Roskoschinski Ph. 2011. Exercitii Militaris - Die vier hölzernen Übungsschwerter vom Bohlenweg XXV (Pr). In: M. Fansa, F. Both (eds.), “O, schaurig ist's, übers Moor zu gehen”. 220 Jahre Moorarchäologie. Begleitschrift zur Ausstellung im Landesmuseum Natur und Mensch Oldenburg 2011. Bad Langensalza, 189-198.

Sarnowska W. 1955. Miecze wczesnośredniowieczne w Polsce. "Światowit" 21, 276-323.

Sarnowska W. 1956. Wojsko polskie w okresie plemiennym. "Dawna Kultura" 3(1), 46-55.

Sawicki T. 2008. Wczesnośredniowieczne cmentarzysko szkieletowe w Daniszewie pod Kotem, woj. wielkopolskie. "Slavia Antiqua" 49, 149-209.

Sawicki W. 1969. Drużyna panującego w niektórych państwach średniowiecznych (X-XIII wiek). "Annales Universitatis Mariae Curie-Skłodowska", sectio G, 16(4), 123-182.

Sayer D., Sebo E., Hughes K. 2019. A Double-edged Sword: Swords, Bodies, and Personhood in Early Medieval Archaeology and Literature. "European Journal of Archaeology" 22(4), 542-566.

Schatte T. 2013. Tüllenspitzen aus Knochen und Geweih. "Mitteilungen der Berliner Gesellschaft für Anthropologie, Ethnologie und Urgeschichte" 34, 91-110.

Sierosławski A., Weker W. 2013. Non-destructive Examination of Spearheads from the Cemetery in Konskie, the Końskie District. "Fasciculi Archaeologiae Historicae" 26, 41-49.

Sikora J. 2014. Groby wojowników, groby z broniq. Uwagi o wczesnośredniowiecznym rytuale deponowania uzbrojenia w grobach. In: W. Dzieduszycki, J. Wrzesiński (eds.), Królowie i biskupi, rycerze i chłopi-identyfikacja zmartych. Funeralia Lednickie 16. Poznań, 297-311.

Stępnik T. 2009. Elitarne cmentarzysko z przełomu XI/XII wieku w Koninku, stan. 65, woj. wielkopolskie. „Folia Praehistorica Posnaniensia" 15, 265-304.

Stępnik T., Kucypera P., Pudło P., Rybka K. 2014. Early-medieval Sword from Koninko, Kórnik Community, Wielkopolskie Voivodeship. "Acta Militaria Mediaevalia" 10, 143-159.

Strzyż P. 2006. Uzbrojenie we wczesnośredniowiecznej Małopolsce. Acta Archaeologica Lodziensia 52. Łódź.

Tokarski W. 1997. Średniowieczne militaria jako wyznaczniki chronologii. In: J. Olczak (ed.), Studia z archeologii, historii i geografii historycznej. Archaeologia Historica Polona 6. Toruń, 55-68.

Tollerton L. 2011. Wills and Will-Making in Anglo-Saxon England. Woodbridge.

Traschel M. 2005. Kriegergräber? Schwertbeigabe und Praktiken ritueller Bannung in Gräbern der frühen Eisenzeit. In: R. Karl, J. Leskovar (eds.), Interpretierte Eisenzeiten. Fallstudien, Methoden, Theorie. Tagungsbeiträge der 1. Linzer Gespräche zur interpretativen Eisenzeitarchäologie. Linz, 53-82.

Vandkilde H. 2006. Warfare, Weaponry, and Material Culture: An Introduction. In: T. Otto, H. Thrane, H. Vandkilde (eds.), Warfare and Society. Archaeological and Social Anthropological Perspectives. Aarhus, 483-490.

Weski T. 1994. Waffen aus organischem Material bei den Germanen und schriftliche Quellen. Ein Beitrag zu einem Zirkelschluß. In: D. Vorlauf (ed.), Festschrift für Otto-Herman Frey zum 65. Geburtstag. Marburger Studien zur Vor- und Frühgeschichte 16. Marburg, 691-703.

Wrzesiński J. 1997-1998. Groby z mieczami na terenie Polski wczesnopiastowskiej. „Prace i Materiały Muzeum Archeologicznego i Etnograficznego w Łodzi. Seria Archeologiczna" 40, 7-46. 
Zawadzka-Antosik B. 1973. Wczesnośredniowieczne cmentarzysko w obudowie kamiennej w Grzebsku, pow. Mława. ,Wiadomości Archeologiczne” 38(3-4), 461-492.

Zemitis G. 2006. Pogrebeniya so spetsial'no povrezhdennym mogil'nym inventarem. In: V. V. Ivanov (ed.), Baltoslavyanskiye issledovaniya 17. Moskva, 394-412.

Żmudzki P. 2004. Najemnicy na Rusi i w krajach sąsiednich w X-XII w. „Kwartalnik Historyczny” 111(4), 5-28.

Żmudzki P. 2005. Mieszko i Amazonki. Wspólnoty wojownicze i normy życia rodzinnego w relacji Ibrahima ibn Jakuba. In: B. Trelińska (ed.), Tekst źródła - krytyka - interpretacja. Warszawa, 99-126.

Żmudzki P. 2009. Władca $i$ wojownicy. Narracje o wodzach, drużynie i wojnach w najdawniejszej historiografii Polski i Rusi. Wrocław.

Żygulski Z. Jr. 1975. Broń w dawnej Polsce na tle uzbrojenia Europy i Bliskiego Wschodu. Warszawa. 